\title{
Evaluacija kvalitete urbanoga susjedstva - prednosti i nedostaci neposrednoga životnog prostora
}

Lana Slavuj

Prirodoslovno-matematički fakultet, Geografski odsjek, Sveučilište u Zagrebu, Hrvatska

e-mail: lslavuj@geog.pmf.hr

\begin{abstract}
SAŽETAK Posljednjih desetljeća u svijetu je pokrenut niz projekata i programa usmjerenih na poboljšanje stanja života u gradovima. Takva istraživanja pokazatelj su želje za mjerenjem, razumijevanjem i važnosti kvalitete života u gradu. Osnovni im je cilj sustavno mjerenje i evaluacija trendova u urbanom prostoru preko niza specifičnih indikatora relevantnih za svakodnevnu kvalitetu života ljudi. Ovaj rad posvećen je istraživanju kvalitete života u odabranim dijelovima Grada Rijeke. Riječ je o pet dijelova grada: Belveder/Brajda-Dolac, Pećine, Pehlin, Orehovica i Pašac. Glavna istraživačka metoda bio je anketni upitnik koji je proveden u kolovozu 2010. godine, na sustavnom slučajnom uzorku stanovnika starijih od 18 godina. U istraživanju je sudjelovalo ukupno 365 ispitanika. U prvom dijelu rada analizira se ukupno iskustvo kvalitete života, pri čemu se kao indikator koristi zadovoljstvo susjedstvom. Susjedstvo se smatra najrelevantnijom razinom za mjerenje jer predstavlja neposredan životni prostor u kojem se odvija većina aktivnosti tijekom dana. Drugi dio rada posvećen je analizi odgovora na pitanja koja se odnose na glavne prednosti i nedostatke ispitanikova susjedstva, njihovih prijedloga što bi trebalo učiniti kako bi se poboljšala kvalitete života u susjedstvu, te mišljenja o tome u kojem će se smjeru razvijati kvaliteta života u narednom petogodišnjem razdoblju. Usporedbe gradskih susjedstva, identifikacija problema kao i prednosti proučavanih dijelova grada za život, predstavljaju bazu informacija koje mogu upoznati građane i predstavnike gradske vlasti o trendovima u kvaliteti života u odabranim susjedstvima Rijeke, te poslužiti u razvoju gradskih projekata i akcija za poboljšanje kvalitete života.
\end{abstract}

Ključne riječi: kvaliteta života u gradu, projekti za praćenje stanja kvalitete života u gradu, zadovoljstvo susjedstvom, prednosti i nedostaci života u susjedstvu, Grad Rijeka. 


\title{
1. Uvod
}

\begin{abstract}
"Mjesta gdje ljudi žive utječu na njihovo zdravlje i mogućnosti da vode uspješne živote. Stoga su zajednice i susjedstva koje omogućavaju pristup osnovnim potrebama, u kojima postoji socijalna kohezija, koje su dizajnirane da promoviraju dobro fizičko i psibičko blagostanje $i$ u kojima se cijeni prirodni okoliš, nužne za postizanje jednakosti u zdravlju i kvaliteti života. Urbana područja često su nezdrava mjesta za život, međutim, postoje načini kojima se mogu nadići ti izazovi" (World Health Organization, Urban Health, 2008.).
\end{abstract}

Sve jasnija spoznaja o utjecaju urbanoga okoliša na kvalitetu života stanovnika i drugih korisnika gradskoga prostora, odražava se u ključnoj ulozi koja se pitanjima urbanoga okoliša posvećuje u strategijama i programima vlada, internacionalnih institucija, te u lokalnim zajednicama. Jedan od najpoznatijih programa održivoga razvoja, Agenda 21, naglašava potrebu djelovanja na svim prostornim razinama pa se govori i o Lokalnoj Agendi 21. Lokalnom Agendom 21 opće odredbe iz Agende 21 prenose se u planove i aktivnosti u lokalnoj zajednici, a osnovni cilj je njeno poboljšanje i očuvanje kvalitete života za buduće generacije (Local Agenda 21, 2011.). Ovaj program služi kao okvirna podrška održivom razvoju u lokalnim sredinama, definirajući na generalan način najvažnije postavke za njegovo uspješno provođenje. Ključne su odredbe programa: uključivanje što većega broja pripadnika lokalne zajednice u proces odlučivanja, prepoznavanje prednosti i nedostataka lokalnih resursa, integracija ciljeva održivoga razvoja u politike lokalnih vlasti, podizanje svjesnosti i obrazovanje stanovnika, mjerenje, evaluacija i izvještavanje o pokrenutim projektima (ibid.). Lokalne zajednice pozvane su da same odrede svoj put prema održivom razvoju i očuvanju kvalitete života, s obzirom na njihove specifičnosti i raznolikost. Program Lokalna Agenda 21 postavio je općenite smjernice za postizanje održivoga razvoja, no danas postoje i mnogi drugi programi.

Primjerice, Europska komisija od 2003./2004. godine provodi projekt za proučavanje stanja kvalitete života u europskim gradovima pod nazivom Urban Audit. U navedeni projekt 2006./2007. godine (druga serija istraživanja) uključen je 321 grad iz 27 članica Europske Unije, te dodatnih 36 gradova iz Norveške, Švicarske i Turske. Projekt primjenjuje oko 250 indikatora za prikupljanje informacija o demografiji, socijalnim i ekonomskim aspektima, građanskoj aktivnosti, obrazovanju, turizmu, prometnoj situaciji, informatičkom društvu, kulturi i rekreaciji u tim gradovima. Projekt prikuplja podatke na tri prostorne razine: urbana regija, grad, unutargradska područja. Provodi se svake tri godine, iako je namjera da se prikupljanje indikatora odvija na godišnjoj bazi (Urban Audit, 2011.). Glavna ideja projekta jest da su gradskim vlastima potrebne pouzdane informacije za urbano planiranje, održiv i prosperitetni razvoj. Stoga su glavni ciljevi Urban Audita osiguravanje ažuriranih i provjerenih podataka koji će informirati javnost i stručnjake o stanju kvalitete života u gradovima, omogućiti usporedbe i razmjenu iskustva među gradovima, te pomagati gradskim vlastima u revidiranju i postavljanu ciljeva. Kao posebna vrijednost 
ističe se prikupljanje podataka na razini gradskih susjedstva, odnosno na razini koja se zaista tiče ljudi i koja direktno utječe na njihovo iskustvo svakodnevnoga života (Šteinbuka, 2008.).

U skladu s idejama Lokalne Agende 21, praćenje i evaluacija kvalitete života u gradovima postaje sve češće dio projekata koje pokreću same lokalne zajednice. Barsell i Maser (2004.) navode da je danas preko 200 zajednica u SAD-u i preko 589 na svijetu uključeno u provođenje ovakvih istraživanja i programa (primjerice: Sustainable Seattle, 2011.; Detroit Area Study, 2001.; Quality of Life Progress Report of Jacksonville and Northeast Florida, 2009. i dr.). Važnost evidentiranja stanja kvalitete života u gradovima prepoznale su do danas mnoge urbane sredine. Svaki takav projekt prilagođen je specifičnostima prostora i kulturnim kontekstima, no ciljevi su im zajednički - sustavno mjerenje i evaluacija trendova u urbanom okolišu preko niza specifičnih indikatora relevantnih za svakodnevnu kvalitetu života ljudi.

Prednosti praćenja stanja kvalitete života u gradu su višestruke. Leitmann (1999.:173) navodi četiri glavna razloga zašto je važno istraživati kvalitetu života u gradu, odnosno što takva istraživanja omogućuju lokalnim vlastima i lokalnom stanovništvu:

1. uspoređivanje unutargradskih susjedstva

2. identifikaciju problema i prioritetnih područja grada

3. razvoj projekata i mjera

4. praćenje i evaluaciju rezultata pokrenutih projekata i mjera.

Usporedbom rezultata mjerenja kvalitete života unutar nekoga grada, lokalnim je upravama i samim stanovnicima omogućeno da prepoznaju probleme koji se ističu u pojedinim dijelovima grada. Indikatori koji se primjenjuju u istraživanju mogu ukazati na razloge koji su doveli do takve nejednakosti. Detaljne prostorne analize mogu se koristiti za identifikaciju koncentracije određenih grupa s posebnim zahtjevima. Primjerice, prepoznavanje grupiranja starijih ili mlađih stanovnika u prostoru grada omogućava planiranje razvoja odgovarajućih usluga i informiranu distribuciju resursa, poput dodatnoga osiguravanja gerijatrijskih ili pedijatrijskih usluga, dječjih igrališta i sl. Upravo je prepoznavanje i identifikacija prostornih uzoraka početna točka u upravljanju i poboljšanju lokalnih uvjeta (Pacione, 1986.; 2003.).

Rezultati studija mogu pomoći planerima i gradskim vlastima da dokumentiraju problematična područja unutar grada, glavne razloge nezadovoljstva, utjecaj demografskih faktora na percepciju objektivnih uvjeta i prioritete samih građana (Ibrahim i Chung, 2003.). Sudjelovanje javnosti u istraživanjima kvalitete života donosi vrijednu povratnu informaciju o efikasnosti javnih usluga, obrascima kretanja, korištenju raznih objekata i usluga, te općenito o mišljenjima o pitanjima poput sigurnosti, dostupnosti, participaciji u radu lokalne zajednice i sl. Osim evaluacije postojećih projekata, stavovi i razmišljanja samih stanovnika pružaju temeljnu podršku za definiranje budućih programa razvoja, planiranje strategija i gradskih projekata (Santos i Martins, 2007.; Kitchen i Muhajarine, 2008.). Također, rezultati takvih istraživanja mogu pomoći i pojedincima u njihovim odlukama gdje živjeti. Implementacija redovitoga sustava motrenja kvalitete života vodi boljem razumijevanju socijalnih i ekonomskih trendova u gradu. Svjesnost o prostornim nejedna- 
kostima u kvaliteti života i stalna potreba za povratnim informacijama o lokalnim uvjetima, trebali bi biti neizostavan dio svakoga procesa planiranja. Kao što Tuan Seik (2000.:46) navodi “...često se spominje da je kvaliteta života stanounika jedan od glaunih ciljeva gradskih vlasti $i$ urbanih planera. Ako je zaista tako, onda bi redovite studije o kvaliteti života trebale biti od neprocjenjive važnosti u planiranju razvoja gradova".

\section{Kvaliteta života u Rijeci - metodološki okvir}

U ovom istraživanju kvaliteta života u gradu shvaćena je kao subjektivno iskustvo stanovnika, odnosno kao zadovoljstvo neposrednim mjestom stanovanja. Glavni cilj istraživanja jest analizirati koliko dobro neposredni životni prostor zadovoljava potrebe i očekivanja stanovnika koji žive u tom prostoru.

Istraživanje je provedeno u pet odabranih susjedstava Grada Rijeke, odnosno na Belvederu/Brajdi-Dolcu, Pećinama, Pehlinu, Orehovici i Pašcu (slika 1.). Odabrani dijelovi Rijeke razlikuju se s obzirom na: demografsku strukturu stanovništva, prosječnu gustoću naseljenosti (najveća je na području Belvdera/Brajde-Dolca, te iznosi 204,93 stanovnika/ha, dok je na Pašcu i Orehovici među najmanjima u Gradu, odnosno manja od 20 stanovnika/ha), fizionomska obilježja (na ispitivanim dijelovima Pehlina, Pašca i Orehovice prisutan je samo tip obiteljskih kuća s jednim ili više stanova, na Belvederu/Brajdi-Dolcu prevladavaju višestambeni objekti, a na Pećinama su prisutna oba tipa izgradnje) i poziciju unutar strukture grada (slika 1.). Osnovna istraživačka metoda bio je anketni upitnik koji je proveden u kolovozu 2010. godine, na sustavnom slučajnom uzorku stanovnika starijih od 18 godina. U istraživanju je sudjelovalo ukupno 365 ispitanika, od toga s Belvedera/ Brajde-Dolca - 70, Pećina - 76, Pehlina - 88, Orehovice - 78, te s Pašca - 53 ispitanika. Najveći udio stanovništva staroga 65 i više godina prikupljen je u uzorku na Pećinama (35,5\%), dok je najveći udio mlađih dobnih skupina (18 - 30 godina) prisutan u uzorku s Pehlina (31,8\%). Najveći udio ispitanika sa završenim fakultetom je u uzorku s Belvedera/Brajde-Dolca (32,9\%), a najmanji s Orehovice (6,4\%) i Pehlina (6,8\%). Najveći udjeli najviših prosječnih mjesečnih primanja kućanstva (više od $14.500 \mathrm{kn}$ ) prisutni su u uzorcima s Pećina (10,5\%) i Belvedera/Brajde-Dolca (10\%), dok su najmanji u uzorku s Orehovice (1,3\%), odnosno Pašca gdje niti jedan ispitanik nema primanja viša od navedenoga (za detalje vidi Slavuj, 2011.).

U anketnom istraživanju ispitanici su zamoljeni da evaluiraju kvalitetu svojega života u susjedstvu, odnosno da izraze razinu zadovoljstva susjedstvom kao mjestom za život na mjernoj skali od 1 do 5 (pri čemu 1 označava u potpunosti nezadovoljan, a 5 u potpunosti zadovoljan). Također, zamoljeni su da navedu glavne prednosti i nedostatke svojega susjedstva, te predlože ideje koje bi dovele do poboljšanja kvalitete života u susjedstvu. 
Slika 1.

Karta Grada Rijeke s odabranim susjedstvima u kojima je provedeno anketno istraživanje

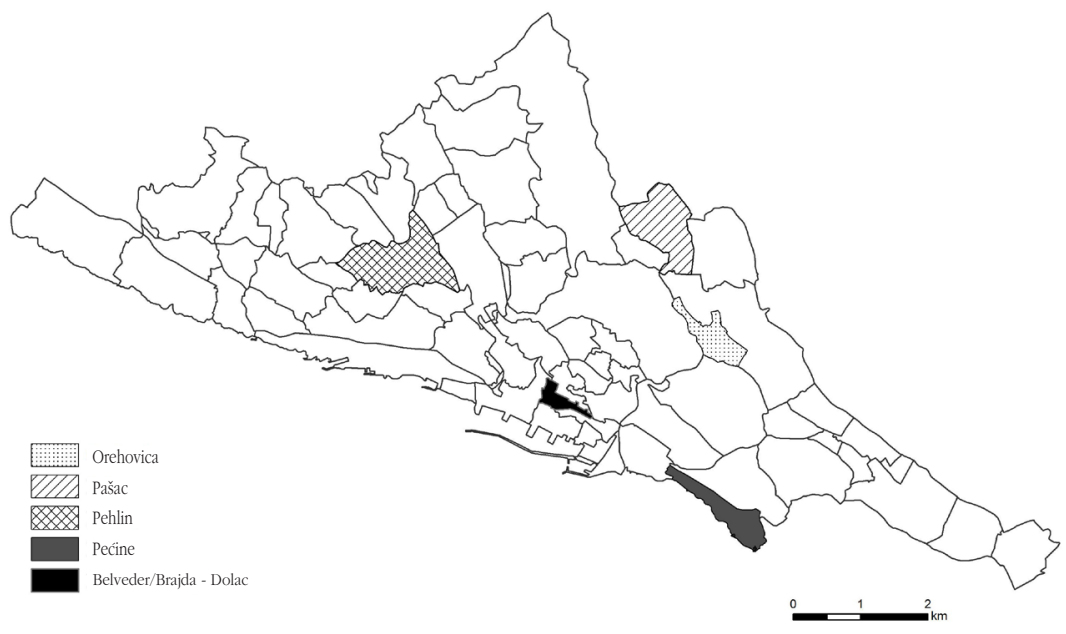

\subsection{Zadovoljstvo susjedstvom kao integralni pokazatelj kvalitete života u gradu}

Kvaliteta života u gradu iznimno je složen, višedimenzionalan koncept koji se uglavnom nastoji mjeriti putem velikoga broja različitih indikatora. Međutim, u istraživanjima ove problematike također su prisutni pokušaji da se prikupe podaci o ukupnom iskustvu kvalitete života. U te su svrhe razvijeni brojni indeksi kvalitete života koji najčešće nastaju sumiranjem rezultata po sastavnim domenama koje čine koncept. Također, takva se cjelovita informacija može dobiti postavljanjem izravnoga pitanja ispitanicima.

U ovom radu kao indikator ukupne kvalitete života u gradu koristi se izravno pitanje o zadovoljstvu ispitanika susjedstvom. Upotreba takve sveobuhvatne, ujedinjujuće mjere, primjeren je način na koji se može obuhvatiti i mjeriti utjecaj mnogih, na drugačije načine, percipiranih dimenzija susjedstva. Izraženo ukupno zadovoljstvo predstavlja pojedinčevu integralnu percepciju susjedstva, koja obuhvaća široki spektar vanjskih uvjeta. Stoga se, zadovoljstvo susjedstvom smatra univerzalnim konceptom koji je dovoljno širok da prihvati različitost prioriteta i važnosti koje za različite ljude nose pojedine značajke njihovoga neposrednog životnog prostora (Parkes, Kearns i Atkinson, 2002.; Lu, 1999.).

Dakle, kako bi se prikupila informacija o kvaliteti života u odabranim dijelovima Rijeke, primijenjeno je sljedeće pitanje: "Koliko ste ukupno zadovoljni ovim susjedstvom kao mjestom za život?' Isto ili slično pitanje primijenjeno je u i drugim istraživanjima (Oktay, Rüstemli i Marans, 2009.; Parkes i sur., 2002.; Lu, 1999.). Pri 
tome, viša razina zadovoljstva susjedstvom znači i veću kvalitetu života. Susjedstva se smatraju relevantnom razinom za mjerenje kvalitete života u gradu jer predstavljaju neposredan životni prostor u kojem se odvija većina dnevnih aktivnosti stanovnika (Pacione, 1982.). Međutim, treba napomenuti da pojam susjedstvo u upitniku nije bio striktno definiran, osim napomene da predstavlja najbliži životni prostor, do 15 minuta hoda od doma. Naime, vrlo je teško jednoznačno odrediti što je to susjedstvo, kad ono za svakoga pojedinog stanovnika može imati drugačije značenje i biti drugačije percipirano. Kao što naglašava Chaskin (1998.; prema Lewis i Klein, 2006.) različite socijalne grupe doživljavaju i koriste susjedstvo na drugačije načine. Ili drugim riječima, definicija susjedstva uvelike ovisi o tome tko definira, te koja je njegova socijalna i fizička pozicija unutar urbane strukture (Guest i Lee, 1984.). Stoga je u istraživanju, definicija granica susjedstva ostavljena samim ispitanicima, što se smatra primjerenim pristupom (Lu, 1999.; Lovejoy, Handy i Mokhtarian, 2010.; Amérigo and Aragoéns, 1997.). Bez obzira na nemogućnost jednoznačnoga razgraničavanja susjedstva unutar grada, za pojedince predstavljaju realnost u kojoj svakodnevno žive.

Na slici 2. prikazani su rezultati dobiveni na ovo pitanje po susjedstvima. Može se vidjeti da su prosječne razine zadovoljstva susjedstvom vrlo slične. Ipak, od promatranih dijelova grada, prosječno zadovoljstvo susjedstvom najviše je na Pećinama (4,03). Slijedi Orehovica (3,73), zatim Pehlin (3,63), Belveder/Brajda-Dolac $(3,56)$, a najniže prosječno zadovoljstvo, među ispitivanim susjedstvima, iskazali su ispitanici s Pašca $(3,47)$.

\section{Slika 2.}

Prosječno zadovoljstvo susjedstvom u odabranim susjedstvima

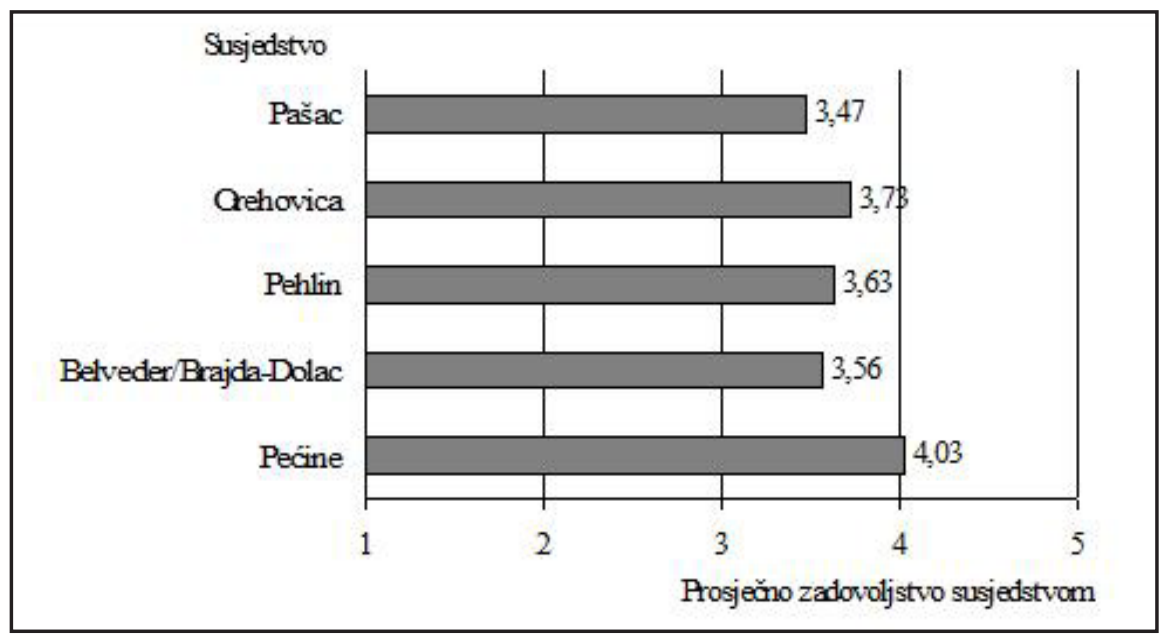

Kako bi se utvrdilo razlikuju li se prosječne razine zadovoljstva susjedstvom, među ispitanicima iz odabranih susjedstava provedena je jednosmjerna analiza varijance (ANOVA). 
Analiza je potvrdila da postoje značajne statističke razlike u prosječnom zadovoljstvu susjedstvom među ispitanicima (Welch $\mathrm{F}(4,172,55)=6,27, \mathrm{p}<0,001$., Brown-Forsythe $\left.\mathrm{F}(4,330,86)=5,65, \mathrm{p}<0,001^{1}\right)$. Detaljnija analiza post hoc testom otkrila je da su ispitanici s Pećina značajno zadovoljniji susjedstvom u odnosu na ispitanike $s$ Belvedera/Brajde-Dolca, Pehlina i Pašca.

Pregledom rezultata dobivenih na ukupnom uzorku (N 365), ustanovljeno je da je većina ispitanika iskazala zadovoljstvo susjedstvom. Naime, uglavnom zadovoljno je 53,4\% (195) ispitanika, a u potpunosti je zadovoljno 11,5\% (42) ispitanika, što čini 64,9\% (237) ukupno zadovoljnih susjedstvom. S druge strane, susjedstvom je uglavnom nezadovoljno 4,9\% (18) ispitanika, a u potpunosti nezadovoljno je samo 1,1\% (4) ispitanika u uzorku. Ispitanika koji su se izjasnili kao niti zadovoljni niti nezadovoljni ima 28,8\% (106). Sklonost ljudi da daju procjene zadovoljstva koje su uglavnom usmjerene na pozitivnu stranu skale, dobro je poznat efekt u istraživanjima kvalitete života. Mnoge studije otkrile su tendenciju k pozitivnoj evaluaciji susjedstva (Marans i Rogers, 1975.; Campbell, Converse i Rodgers, 1976.; Lu, 1999.; Lovejoy i sur., 2010.). U literaturi se kao potencijalna objašnjenja ovoga efekta najčešće navode:

- tendencije pojedinaca da se naviknu i prilagode na okoliš stanovanja iz kojega nemaju mogućnosti odseliti, pogotovo u slučaju ukoliko su im lako dostupni resursi izvan njihovoga neposrednog mjesta stanovanja (Lu, 1999.; Wellman i Wortley, 1990.);

- mogućnost da se pojedinci naseljavaju u susjedstvima koja preferiraju (Lee, Oropesa i Kanan, 1994.);

- mogućnost da takvo rašireno davanje iskaza zadovoljstva odražava nedostatak brige ili interesa za susjedstvo (Parkes i sur., 2002.).

No, najvjerojatnije je da na ovakve rezultate određeni utjecaj imaju svi navedeni faktori zajedno, odnosno da se te mogućnosti prožimaju, kako međusobno, tako i s nekim drugim potencijalnim razlozima.

Analiza rezultata na pitanje o zadovoljstvu susjedstvom, odnosno upotreba cjelovite mjere, ukazala je na trendove koji postoje u ovim susjedstvima Rijeke. Analiza je pokazala da ispitanici većinom pozitivno ocjenjuju mjesto gdje žive, ali i da su (iako su prosječne razine zadovoljstva slične) ispitanici s Pećina značajno zadovoljniji susjedstvom u odnosu na sve druge ispitanike, osim na ispitanike s Orehovice. Drugi dio istraživanja posvećen je konkretnijim pitanjima koja su primijenjena kako bi se preciznije identificirali elementi koji su važni za svakodnevnu kvalitetu života u susjedstvu.

1 Pokazatelji Welch F i Brown-Forsythe F primijenjeni su zbog nehomogenosti varijance. 


\subsection{Negativna i pozitivna obilježja susjedstva, te preferencije ispitanika}

Kako bi se detaljnije upotpunila slika o kvaliteti života u odabranim susjedstvima, ispitanicima su u anketnom upitniku postavljena pitanja otvorenoga tipa. Pitanja su se odnosila na nedostatke i prednosti susjedstva u kojem žive, te na ideje o tome što bi trebalo učiniti kako bi se popravila kvaliteta života u njihovom susjedstvu. Također, ispitanici su pitani za mišljenje u kojem će se smjeru razvijati kvaliteta života u susjedstvu u narednih pet godina. Pet najčešćih odgovora na pitanje o nedostacima susjedstva gdje anketirani žive navedeni su prema susjedstvima. Ispitanici su mogli navesti više odgovora, a postoci u zagradama predstavljaju udio pojedinoga odgovora u ukupnom broju svih odgovora.

Na Belvederu/Brajdi-Dolcu glavni nedostaci su:

1. nedostatak parkirališnih mjesta $(36,4 \%)$

2. nedostatak zelenih površina (20\%)

3. nedostatak dječjih i sportskih igrališta (14,3\%)

4. prevelik promet, buka i gužve $(12,1 \%)$

5. zapuštene i oronule zgrade $(7,1 \%)$.

Na Pećinama glavni nedostaci su:

1. nedostatak parkirališnih mjesta $(21,7 \%)$

2. preveliki promet, buka i gužve $(14,5 \%)$

3. nedostatak dječjih i sportskih igrališta $(13,2 \%)$

4. zapuštenost i neuređenost postojećih zelenih površina (10,5\%)

5. međususjedski odnosi (7,2\%).

Na Pehlinu najveći nedostaci su:

1. nedovršena komunalna infrastruktura (kanalizacija, gradski plin) (21\%)

2. kuće su nagurane/preblizu jedna drugoj (13,3\%)

3. loša kvaliteta cesta $(10,8 \%)$

4. međususjedski odnosi (10,2\%)

5. zapuštenost i neuređenost postojećih zelenih površina $(7,7 \%)$.

Na Orehovici najveći nedostaci su:

1. nedostatak uslužnih, obrazovnih i zdravstvenih djelatnosti (trgovine za svakodnevnu opskrbu, vrtić, ljekarna) (25,6\%)

2. nedovršena komunalna infrastruktura (kanalizacija, odvodnja oborinskih voda, gradski plin) $(17,9 \%)$

3. nedostatak sadržaja/prostora za umirovljenike $(12,2 \%)$

4. nedostatak sadržaja/prostora za mlade $(11,9 \%)$

5. neravan/skučen teren $(5,8 \%)$.

Na Pašcu glavni nedostaci su:

1. slab javni gradski prijevoz (22,6\%)

2. nedostatak uslužnih, obrazovnih i zdravstvenih djelatnosti (trgovine za svakodnevnu opskrbu, vrtić, pošta, banka, ljekarna, ambulanta) (20,8\%)

3. nedostatak nogostupa $(13,2 \%)$ 
4. izoliranost/periferni položaj (10,4\%)

5. nedostatak sadržaja/prostora za mlade $(8,5 \%)$.

Iz navedenih nedostataka vidljivo je da ispitana susjedstva imaju svoje specifične probleme, ali i mnoge koji su im zajednički. Primjerice, Belveder/Brajda-Dolac i Pećine imaju međusobno najsličnije nedostatke. Problem parkinga, manjak i neodržavanje zelenih površina, prometne gužve i buka, karakteristični su nedostaci života u centru grada ili u njegovoj neposrednoj blizini. Treći najčešće spominjani nedostatak u ova dva susjedstva manjak je dječjih i sportskih igrališta. Očigledno, ovaj nalaz ukazuje da se najmlađi stanovnici grada ne uvažavaju dovoljno, odnosno da njihove potrebe nisu prepoznate. Anketirani na Belvederu/Brajdi-Dolcu navode i zapušten izgled zgrada, a ispitanici s Pećina međususjedske odnose.

Na Pehlinu se ispitanici žale na nedovršenu komunalnu infrastrukturu, prije svega na manjak kanalizacijskoga sustava i sustava gradskoga plina. Također, anketirani smatraju nedostatkom postojeći raspored stambenih objekata, te navode da su kuće nagurane i izgrađene preblizu jedna drugoj. Kao negativan aspekt ističu i ceste koje su loše kvalitete, preuske i neplanski građene. Nadalje, ispitanici spominju međususjedske odnose, te zapuštenost i neuređenost postojećih zelenih površina. Susjedstva s gradske periferije, Orehovica i Pašac, imaju drugačije nedostatke. Generalno, ispitanike muči nedostatak sadržaja, odnosno uslužnih, obrazovnih i zdravstvenih djelatnosti, te nedostatak prostora i sadržaja za mlade i umirovljenike. Anketirani na Orehovici kao negativan aspekt susjedstva ističu nedovršenu komunalnu infrastrukturu, odnosno kanalizacijski sustav, sustav odvodnje oborinskih voda i nemogućnost priključka na plinsku mrežu². Također, navode neravan i skučen teren.

Anketirani s Pašca kao glavni nedostatak susjedstva vide slab te potrebama neprilagođen javni gradski prijevoz. Također, navode periferni položaj i izoliranost, što je vjerojatno djelomično povezano i sa spomenutom neadekvatnom organizacijom autobusnih linija. Ispitanici se žale i na nedostatak nogostupa.

Kada se ovi odgovori usporede s rezultatima istraživanja koje su u Rijeci proveli Rogić, Lamza-Posavec, Klemenčić i Kovačić-Pašalić (1996.), vidljivo je da su nedostaci koje su ispitanici navodili tada i danas gotovo identični. Naime, nedostatak dječjih igrališta, slab javni prijevoz, slabe lokalne ceste, oskudno i neuređeno zelenilo, oskudna komunalna oprema naselja (usluge, parkirališta, itd.) i zapuštene stambene zgrade, glavni su nedostaci koje su identificirali u svom istraživanju (ibid.). Očigledno, riječ je o dugo prisutnim problemima za koje se u razdoblju od 14 godina nije uspjelo pronaći rješenje.

Na pitanje o prednostima susjedstva u kojem žive, ispitanici su također mogli dati više odgovora. Postoci u zagradama predstavljaju udio pojedinoga odgovora u ukupnom broju svih odgovora.

${ }^{2}$ U razdoblju provedbe istraživanja u kolovozu 2010. godine radovi na komunalnoj infrastrukturi u naselju Orehovica, iako planirani, još nisu bili započeti. 
Glavne prednosti života na Belvederu/Brajdi-Dolcu su:

1. dostupnost svih potrebnih sadržaja (48,6\%)

2. blizina centra grada $(31,4 \%)$

3. blizina radnoga mjesta $(5,7 \%)$

4. blizina bolnice $(4,3 \%)$

5. blizina škola i fakulteta (3,6\%).

Glavne prednosti života na Pećinama su:

1. blizina mora $(30,3 \%)$

2. blizina centra grada $(22,4 \%)$

3. dostupnost svih potrebnih sadržaja / Tower centar Rijeka $(18,2 \%)$

4. zelene površine $(10,5 \%)$

5. individualizam i privatnost $(5,3 \%)$.

Glavne prednosti života na Pehlinu su:

1. mir i tišina $(26,1 \%)$

2. blizina centra grada $(20,5 \%)$

3. dostupnost svih potrebnih sadržaja $(15,9 \%)$

4. zelene površine $(12,5 \%)$

5. obiteljska kuća s vlastitim dvorištem/vrtom (6,8\%).

Glavne prednosti života na Orehovici su:

1. zelene površine $(23,1 \%)$

2. mir i tišina $(19,2 \%)$

3. poznata lica/prijatelji/druženje sa susjedima (18,4\%)

4. Život u manjoj sredini izvan grada, ali dovoljno blizu (12,2\%)

5. čišći zrak nego u centru (5,1\%).

Glavne prednosti života na Pašcu su:

1. mir i tišina $(32,1 \%)$

2. zelene površine $(28,3 \%)$

3. poznata lica/prijatelji/druženje sa susjedima (17\%)

4. Život u manjoj sredini izvan grada, ali dovoljno blizu (10,2\%)

5. obiteljska kuća s vlastitim dvorištem/vrtom (7,5\%).

Na pitanje o prednostima susjedstva dobiveno je manje različitih odgovora nego na pitanje o nedostacima, što pokazuje da ispitanici uglavnom pozitivnim ocjenjuju i vrednuju slične karakteristike okoliša. Ispitanici iz središta grada i njegove blizine kao glavne prednosti navode dostupnost svih potrebnih sadržaja i centra grada. Konkretnije, ispitanicima koji žive na Belvederu/Brajdi-Dolcu sve glavne prednosti vezane su uz dostupnost (centra, radnoga mjesta, bolnice, škole, fakulteta). Također, ovaj je aspekt među najvažnijim prednostima i ispitanicima s Pećina. U svojim odgovorima anketirani, uz blizinu centra i općenito dostupnost svih potrebnih sadržaja, posebno ističu blizinu velikoga trgovačkog centra (Tower centar Rijeka). Ipak, najveća prednost života na Pećinama je blizina mora, a ispitanici još navode zelene površine, te individualizam i privatnost koja vlada među susjedima. Kao što je odgovorio jedan ispitanik "susjedi su tolerantni i ne zabadaju nos u tuđa posla". 
Kada se analiziraju prednosti života na Pehlinu i usporede s ostalim susjedstvima, može se uočiti da ispitanici kao pozitivne strane vide aspekte koji su prisutni i kod tipičnih gradskih susjedstava (Belvedera/Brajde-Dolca i Pećina) i kod susjedstava s gradske periferije. Naime, prednosti života na Pehlinu kombinacija su pozitivnih strana koje nudi grad (dostupnost svih sadržaja i blizina centra), a s druge strane mira i tišine, zelenih površina, kuće s vlastitim dvorištem i vrtom, koje su među glavnim prednostima života na Orehovici i Pašcu.

Ispitanici na Orehovici i Pašcu spominju gotovo identične prednosti. Osim već spomenutih mira i tišine, te zelenih površina, kao pozitivnu stranu ističu socijalne kontakte, odnosno poznata lica, prijatelje, bliskost i druženje sa susjedima. Nadalje, navode da je prednost živjeti u manjoj sredini izvan grada, ali opet biti dovoljno blizu. Ispitanici koriste termin izvan grada koji dobro odražava percepciju stanovnika da njihovo susjedstvo ne pripada gradu, odnosno da nije tipično gradsko. Pozitivne strane života su i čišći zrak, te zadovoljstvo koje pruža vlastito dvorište i vrt.

Ispitanici su pitani što bi se po njima trebalo napraviti kako bi se poboljšala kvaliteta života u susjedstvu gdje žive. Odgovori su uglavnom odraz već navedenih nedostataka, što je očekivano s obzirom da su to glavni problemi za koje bi ispitanici voljeli da se pronađu rješenja. Na Belvederu/Brajdi-Dolcu ispitanici smatraju da bi trebalo riješiti problem parkinga, primjerice gradnjom novih garaža ili oznakama mjesta za stanare. Nadalje, kako jedan ispitanik navodi: "Ako već nema mjesta za nove zelene pouršine ili igrališta, neka se barem urede i bolje opreme postojeća". Takvo je mišljenje prisutno i kod drugih ispitanika. Također, odgovor ispitanice da treba "urediti fasade zgrada kako bi cijelo susjedstvo izgledalo bolje i ljepše", dobro odražava čest stav anketiranih.

Na Pećinama, uz prijedloge koje su isti kao i na Belvederu/Brajdi-Dolcu, ispitanici još navode da bi se trebalo uložiti u prometnice i popraviti nogostupe, za koje se ujedno žale da su zakrčeni automobilima, što ometa slobodno kretanje pješaka. Također, smatraju da je potrebno bolje održavati čistoću na ulicama, te navode, primjerice, problem psećega izmeta na nogostupu. Na Pećinama živi veliki broj staroga stanovništva (prema podacima za 2001. godinu oko 26\% stanovnika Pećina su stariji od 65 godina), ali nema ljekarne ni ambulante, pa ne začuđuje da bi anketirani voljeli da su im ove ustanove dostupnije. Kao jednu od glavnih prednosti života na Pećinama, ispitanici su naveli blizinu mora. Međutim, smatraju da bi plaže trebalo bolje urediti i opremiti, primjerice postaviti tobogane i urediti kafiće na plaži. Ispitanici s Pehlina ponavljaju većinu prijedloga izrečenih na Belvederu/Brajdi-Dolcu i Pećinama, no navode i potrebu rješavanja pitanja otpadnih i oborinskih voda, te plinifikaciju. Također, smatraju da bi stanari veću brigu trebali posvetiti uređenju i održavanju čistoće okućnica.

Kao što je već prikazano u popisu nedostataka, anketirane s Orehovica i Pašca najviše smeta nedostatak sadržaja potrebnih za svakodnevan život, primjerice trgovine mješovitom robom, ljekarne, ambulante, vrtića. Ispitanici s Orehovice željeli bi da se dovrši kanalizacija i provede plinifikacija. Također, problem predstavljaju oborinske vode. Kako navodi jedna ispitanica: "Nema odvodnih kanala, pa kada 
pada kiša zbog vode se ne može hodati po cesti’. Također, ispitanike ovih susjedstava smeta što dio cesta uopće nema nogostup, a na Pašcu ne postoji ni pješački prijelaz. Nadalje, anketirani na Pašcu smatraju da su autobusne linije prerijetke i ne odgovaraju u potpunosti njihovim potrebama. I u jednom i u drugom susjedstvu ispitanici misle da bi trebalo osigurati prostor za druženje, te sadržaje za mlade i starije. Ispitanica s Orehovice navodi: "Mladi se nemaju gdje družiti, osim na cesti. Mi smo se nekad barem družili u domu kulture".

Nadalje, anketirani predlažu da bi se trebale češće održavati različite radionice i predavanja koja bi bila zanimljiva starijima i mladima, te da bi se mogla, primjerice, organizirati rekreacija za umirovljenike i srednju dob.

Jedan stariji ispitanik s Orehovice ovako je komentirao pitanje: "Grad nas je potpuno zaboravio, samo vuku u centar". Navedeni stav prisutan je manje izravno i u odgovorima drugih anketiranih s Orehovice i Pašca. Osim toga, više puta se u ova dva naselja ponavlja mišljenje da bi za poboljšanje kvalitete života trebalo prije svega popraviti standard ljudi i osigurati zaposlenje mještanima. Iako nije posve jasno iz odgovora tko bi trebao utjecati na ove aspekte, je li za to odgovoran Grad ili netko drugi, indikativno je da se ovakvi odgovori pojavljuju samo u ova dva susjedstva.

Pregled najčešćih odgovora na pitanje što bi se trebalo napraviti kako bi se poboljšala kvaliteta života u susjedstvu prema mišljenju anketiranih:

\section{Belveder/Brajda-Dolac}

Riješiti problem parkinga

Opremiti i urediti postojeća dječja i sportska igrališta

Urediti i održavati postojeće zelene površine

Obnoviti fasade zgrada

\section{Pećine}

Proširiti, urediti i održavati postojeće zelene površine

Popraviti prometnice i nogostupe

Riješiti problem parkiranja

Održavati čistoću ulica i nogostupa

Napraviti nova i urediti postojeća igrališta za djecu i sportska igrališta

Otvoriti ambulantu, ljekarnu, trgovine za svakodnevnu opskrbu

Urediti plaže

Obnoviti fasade zgrada 


\section{Pehlin}

Popraviti prometnice i sagraditi nogostupe

Dovršiti sustav kanalizacije i oborinskih voda, plinifikacija

Proširiti, urediti i održavati postojeće zelene površine

Održavati čistoću ulica

Napraviti nova i urediti postojeća igrališta za djecu i sportska igrališta

Urediti okućnice

\section{Orehovica}

Dovesti sadržaje (trgovina za svakodnevnu opskrbu, vrtić, ljekarna)

Dovršiti sustav kanalizacije i oborinskih voda, plinifikacija

Popraviti prometnice, napraviti nogostupe

Više sadržaja/prostora za mlade i umirovljenike

Popraviti standard, zaposlenje mještana

\section{Pašac}

Dovesti sadržaje (trgovine za svakodnevnu opskrbu, vrtić, ljekarna, ambulanta, pošta, kiosk, banka)

Bolja povezanost s centrom grada - češće autobusne linije

Popraviti prometnice, napraviti nogostupe, pješačke prijelaze

Više sadržaja/prostora za mlade i umirovljenike

Popraviti standard, zaposlenje mještana

Nadalje, ispitanici su pitani što misle kakva će za pet godina biti kvaliteta života u njihovom susjedstvu. Odgovori na ovo pitanje prikazani su u tablici 1.

Tablica 1.

Distribucija odgovora na pitanje: "Što mislite kakva ce za pet godina biti kvaliteta života u Vašem susjedstvu?'

\begin{tabular}{|l|c|c|c|c|}
\hline & bit će bolja & ostat će ista & pogoršat će se & ne znam \\
\hline Belveder/Brajda-Dolac & $22,9 \%(16)$ & $27,1 \%(19)$ & $15,7 \%(11)$ & $34,3 \%(24)$ \\
\hline Pećine & $11,8 \%(9)$ & $36,8 \%(28)$ & $18,4 \%(14)$ & $32,9 \%(25)$ \\
\hline Pehlin & $15,9 \%(14)$ & $33,0 \%(29)$ & $21,6 \%(19)$ & $28,4 \%(25)$ \\
\hline Orehovica & $14,1 \%(11)$ & $42,3 \%(33)$ & $15,4 \%(12)$ & $26,9 \%(21)$ \\
\hline Pašac & $9,4 \%(5)$ & $37,7 \%(20)$ & $17,0 \%(9)$ & $34,0 \%(18)$ \\
\hline
\end{tabular}


Među ispitivanim susjedstvima najpozitivnije mišljenje o kvaliteti života u sljedećih pet godina izrazili su anketirani na Belvederu/Brajdi-Dolcu. Naime, njih 22,9\% (16) misli da će kvaliteta života biti bolja. S druge strane, samo 9,4\% (5) ispitanika S Pašca smatra da ce se kvaliteta života u susjedstvu popraviti. Ispitanicima je bilo postavljeno i potpitanje: "Zašto tako mislite?'. Odgovori otkrivaju da iza tih rezultata više stoji njihov vlastiti optimizam nego konkretno znanje o potencijalnim budućim akcijama ili projektima. Gotovo svi ispitanici koji su izabrali ovaj odgovor na Belvederu/Brajdi-Dolcu odgovorili su da su optimisti, te da se moraju nadati da će biti bolje. Identičan odgovor dali su i ispitanici u drugim susjedstvima s nekoliko specifičnih, konkretnih odgovora. Primjerice, anketirani s Pećina misle da će biti bolje zbog novoga tunela i ceste D-404 (spaja centar grada s autocestom), što će smanjiti prometne gužve. Ispitanici s Pehlina navode da se planira gradnja vrtića, plinovoda, popravak cesta, općenito ulaganje u infrastrukturu. Ispitanici s Orehovice smatraju da će se dovršiti kanalizacija, te da će možda dobiti mogućnost priključenja na plinsku mrežu.

Ipak, najčešći odgovor koji su ispitanici dali u svim susjedstvima (izuzev odgovora ne znam koji je također izabrao veliki broj ispitanika) jest da se kvaliteta života u narednih pet godina neće mijenjati. Ponovno, ispitanici na potpitanje zašto tako misle, daju vrlo slične odgovore u svim susjedstvima, odnosno da se slabo ulaže i da se već godinama nije gotovo ništa promijenilo, pa to ne očekuju ni u narednom petogodišnjem razdoblju. Navode još nedostatak financijskih sredstava, nedostatak volje i osoba koje bi bile pokretači promjena. Ispitanik s Belveder/Brajde-Dolca navodi da tako misli jer "Rijeka nije Zagreb", a ispitanik s Pašca jer, kako kaže, "grad slabo ulaže u naše mjesto".

Najviše odgovora da će se kvaliteta života pogoršati u sljedećih pet godina dali su ispitanici s Pehlina $(21,6 \%, 19)$. Neki od razloga za takvo mišljenje su: "sve više ljudi se doseljava, a sve je manje prostora", "prenapučeno je", "zbog eksplozije populacije", "zato što je preko ceste romsko naselje". Ispitanici s Pećina navode da će se kvaliteta života pogoršati zbog širenja kontejnerskoga terminala zbog kojega će i buka biti veća. Jedan ispitanik je naveo da će se pogoršati jer "na Pećinama žive samo stari ljudi". Ispitanik s Pašca slično zaključuje da će biti gore jer "mladi ljudi odlaze, samo stariji ostaju", a isti razlog ponavljaju i ispitanici s Orehovice. Anketirani s Pašca i Orehovice još kao razlog napominju da se ništa ne poduzima, dodatan pad standarda, manjak novca i rast nezaposlenosti.

\section{Zaključak}

U radu su predstavljeni rezultati istraživanja kvalitete života u odabranim susjedstvima Grada Rijeke. Prvi dio rada posvećen je ispitivanju ukupnoga iskustva kvalitete života. U tu svrhu primijenjeno je pitanje o zadovoljstvu susjedstvom kao mjestom stanovanja. Dosadašnja istraživanja pokazala su da je mjera bazirana na jednom, direktnom pitanju dobar pokazatelj jer je sveobuhvatna, odnosno uključuje različitost prioriteta i važnosti koje za različite ljude nose pojedine značajke njihovoga neposrednog životnog prostora. Analiza prosječnih razina zadovoljstva susjedstvom 
pokazala je da je većina ispitanika u uzorku iskazala zadovoljstvo susjedstvom. Kada su uzorci po susjedstvima promotreni odvojeno i testirani jednosmjernom analizom varijance, pokazalo se da su ispitanici s Pećina značajno zadovoljniji susjedstvom u odnosu na sve druge, osim na ispitanike s Orehovice.

Drugi dio rada posvećen je analizi pitanja kojima su pobliže identificirani glavni nedostaci i prednosti susjedstava. Također, prikupljeni su prijedlozi ispitanika o tome što bi trebalo poduzeti kako bi se popravila kvaliteta života u susjedstvu, te njihovo mišljenje o smjeru razvoja kvalitete života u narednom petogodišnjem razdoblju. Ovaj dio rada donosi vrijedne informacije koje mogu pomoći u definiranju gradskih prioriteta i politika razvoja.

Rezultati istraživanja pokazuju da kvaliteta života u gradu znatno ovisi o konkretnom mjestu stanovanja (u stilu engleske izreke place matters!) jer svako od susjedstva ima svoje prednosti i nedostatke. Navedene nedostatke važno je prepoznati kako bi se u budućim projektima izbjegli, a u postojećim susjedstvima popravili, što je više moguće. U tom smislu, rezultati ovoga istraživanja nose važne poruke za pojedine gradske službe. Primjerice, ispitanicima na Pašcu i Orehovici nedostaju neki važni sadržaji (ljekarna, ambulanta, vrtići, škola, trgovine za svakodnevnu opskrbu), te se žale na slab javni prijevoz. Reorganizacija javnoga prijevoza i češće autobusne linije iz centra prema ovim relacijama znatno bi umanjili te nedostatke jer bi olakšali pristup resursima koji nedostaju. Gradske vlasti trebale bi više ulagati u kvalitetu prometnica i voditi računa da se na prometnicama naprave nogostupi jer nedostaju na Orehovici, Pašcu i dijelovima Pehlina, a stanovnici ih smatraju potrebnima za sigurno kretanje ulicom. Ispitanici na Pećinama i Pehlinu nisu zadovoljni uređenjem postojećih zelenih površina pa bi gradske službe zadužene za njihovo održavanje trebale reagirati i posvetiti im veću brigu. Nedovršen sustav kanalizacije i neprovedena plinifikacija smeta ispitanike na Pehlinu i Orehovici pa bi Grad trebao ubrzati razvoj ovih segmenata.

Nadalje, trebalo bi više pažnje posvetiti najmlađim stanovnicima grada i njihovim potrebama. Djeca u gradu jednako su važni korisnici prostora kao i odrasli, ali rezultati pokazuju da se njihovo pravo na dio gradskoga prostora ne uvažava dovoljno. Ispitanici s Belvedera/Brajde-Dolca i Pećina smatraju da nedostaju igrališta za djecu, te sportska igrališta. Prema tome, da bi stanovnici bili zadovoljniji svojim susjedstvima, potrebno je, između ostaloga, napraviti nova, te bolje održavati i opremiti postojeća dječja i sportska igrališta. Podatak o ukupnom broju dječjih igrališta i ukupnom broju djece u Gradu Rijeci zorno pokazuje postojeći nerazmjer. Ukupan broj djece do 15 godina u Gradu je 5.809, a postojeći broj igrališta je 22 za djecu u dobi od 7 do 15 godina, te 137 za djecu od 0 do 6 godina (GUP Grada Rijeke, 2007.). U kontekstu ovoga istraživanja koje pokazuje da su dječja igrališta visoko na ljestvici nedostataka susjedstva, Grad bi trebao ubrzati provedbu odluka o izgradnji novih dječjih igrališta zacrtanih u Generalnom urbanističkom planu Grada Rijeke iz 2007.

Općenito, iz prikupljenih podataka primjećuje se da ljudi većinom cijene i očekuju iste karakteristike od neposrednoga životnog prostora. Nadalje, vrlo im je važna dobra dostupnost usluga i sadržaja. Vrednuju zelene površine i htjeli bi da ih u njihovoj 
neposrednoj blizini ima što više. No, važno im je i održavanje čistoće i urednosti tih zelenih površina. Vrednuju mogućnost da mogu prošetati u blizini svoga doma i odvesti djecu na igru u uređene i opremljene prostore, kao što su dječja i sportska igrališta. Također, cijene mir, siguran okoliš, mogućnost druženja sa susjedima i gajenje prijateljskih veza s ljudima u zajednici, privatnost, mogućnost parkiranja i odsustvo gužvi. Dakle, da bi bili po mjeri čovjeka, gradska susjedstva trebala bi uključivati sve navedene elemente.

Među ključnim postavkama programa koji promovira održivi razvoj i kvalitetu života, Lokalne Agende 21, navodi se važnost prikupljanja znanja o potrebama i prioritetima građana kako bi se na osnovi toga mogli poduzimati koraci i planirati potrebne akcije razvoja. Ovaj rad donosi usporedbe odabranih gradskih susjedstava, identifikaciju problema i prednosti tih dijelova grada za život, čime predstavlja vrijednu bazu informacija. Prikupljeni podaci mogu poslužiti u informiranju građana i predstavnika gradske vlasti o trendovima u kvaliteti života u odabranim susjedstvima Rijeke. Također, prikupljene informacije mogu pripomoći u razvoju gradskih projekata i programa usmjerenih na poboljšanje kvalitete života.

\section{Literatura}

1. Amérigo, M. and Aragonés, J. I. (1997). A theoretical and methodological approach to the study of residential satisfaction. Journal of Environmental Psychology, 17 (1): 47-57.

2. Barsell, K. and Maser, E. (2004). Taking indicators to the next level: Truckee Meadows tomorrow launches quality of life compacts, in: Sirgy M. Joseph, Rahtz Don and Lee Dong-Jin (Eds.). Community Quality of life Indicators, Social Indicators Research Series. Dodrecht: Kluwer Academic.

3. Campbell, A.; Converse, P. E. and Rodgers, W. L. (1976). The quality of American life: perceptions, evaluations and satisfactions. New York: Russell Sage Foundation.

4. Chaskin, R. (2006). Defining neighborhood, in: Lewis Megan S. and Klein William R. (Eds.). Planning and urban design standards. Hoboken, NJ: John Wiley and Sons.

5. Detroit Area Study (DAS) 2001, University of Michigan. Pregledano 20. rujna 2011. (http://www.tcaup.umich.edu/workfolio/DAS2001/partnercities.html).

6. Državni zavod za statistiku (2010). Popis stanovništva, kućanstva $i$ stanova, po statističkim krugovima Grada Rijeke 2001. Zagreb: Državni zavod za statistiku.

7. Generalni urbanistički plan Grada Rijeke, 2007, Grad Rijeka. Pregledano 22. rujna 2011. (http://www.rijeka.hr/Generalni\%20urbanisti\%C4\%8Dki\%20plan).

8. Guest, A. M. and Lee, B. A. (1984). How urbanites define their neighborhoods. Population and Environment, 7 (1): 32-56.

9. Lee, B.A.; Oropesa, R. S. and Kanan, J. W. (1994). Neighborhood Context and Residential Mobility. Demography, 31 (2): 249-270.

10. Leitmann, J. (1999). Can city QOL - indicators be objective and relevant? Towards a participatory tool for sustaining urban development. Local Environment: The International Journal of Justice and Sustainability, 4 (2): 169-180. 
11. Lewis S. M. and Klein R. (2006). Planning and urban design standards. Hoboken, New Jersey: John Wiley and Sons.

12. Local Agenda 21 (2011). Pregledano 12. rujna 2011. (http://www.gdrc.org/uem/ la21/la21.html).

13. Lovejoy, K.; Handy, S. and Mokhtarian, P. (2010). Neighborhood satisfaction in suburban versus traditional environments: An evaluation of contributing characteristics in eight California neighborhoods. Landscape and Urban Planning, 97 (1): 37-48.

14. Lu, M. (1999). Determinants of Residential Satisfaction: Ordered Logit vs. Regression Models. Growth and Change, 30 (2): 264-287.

15. Ibrahim, M. F. and Chung, S. W. (2003). Quality of Life of Residents Living near Industrial Estates in Singapore. Social Indicators Research, 61 (2): 203-225.

16. Kitchen, P. and Muhajarine, N. (2008). Quality of life research: New challenges and new opportunities. Social Indicators Research, 85(1): 1-4.

17. Marans, R. and Rodgers, W. (1975). Toward an understanding of community satisfaction, in: A. Hawley Amos and Rock Vincent (Eds.) Metropolitan America in Contemporary Perspective. New York: Halsted Press.

18. Oktay, D.; Rustemil, A. and Marans, R. (2009). Neighborhood satisfaction, sense of community, and attachment: Initial findings from Famagusta quality of urban life study. ITU A/Z Journal, 6 (1): 6-20.

19. Pacione, M. (1982). The use of objective and subjective measures of quality of life in human geography. Progress in Human Geography, 6 (4): 494-514.

20. Pacione, M. (1986). Quality of life in Glasgow: an applied geographical analysis. Environment and Planning A, 18 (11): 1499-1520.

21. Pacione, M. (2003). Quality-Of-Life Research in Urban Geography. Urban Geography, 24 (4): 314-339.

22. Parkes, A.; Kearns, A. and Atkinson, R. (2002). What Makes People Dissatisfied with their Neighbourhoods?. Urban Studies, 39 (13): 2413-2438.

23. Quality of Life Progress Report of Jacksonville and Northeast Florida, 2009. Pregledano 10. rujna 2011. (http://www.jcci.org/jcciwebsite/documents/09\%20 QOL\%20Summary\%20Document.pdf).

24. Rogić, I.; Lamza-Posavec, V.; Klemenčić, M.; Kovačić-Pašalić, R. (1996). Rijeka: baština za budućnost. Rijeka: Grad Rijeka, Odjel gradske uprave za urbanizam, ekologiju i gospodarenje zemljištem.

25. Santos, L. and Martins, I. (2007). Monitoring Urban Quality of Life: The Porto Experience. Social Indicators Research, 80 (2): 411-425.

26. Slavuj, L. (2011). Kvaliteta života u urbanom okolišu - primjer Grada Rijeke. neobjavljen doktorski rad, Sveučilište u Zagrebu, Prirodoslovno-matematički fakultet, Geografski odsjek.

27. Sustainable Seattle (2011). Pregledano 10. rujna 2011. (http://sustainableseattle. org/).

28. Šteinbuka, I. (2008). Presentation of the Urban Audit. The Urban Audit Measuring the Quality of Life in European cities. Pregledano 10. rujna 2011. (http:// ec.europa.eu/regional policy/conferences/urbanaudit2008/programme en.htm).

29. Tuan Seik, F. (2000). Subjective assessment of urban quality of life in Singapore (1997-1998). Habitat International, 24 (1): 31-49. 
30. Urban Audit (20-11). Pregledano 10. srpnja 2011. (http://www.urbanaudit.org/).

31. Wellman, B. and Wortley, S. (1990). Different Strokes from Different Folks: Community Ties and Social Support. The American Journal of Sociology, 96 (3): 558-588.

32. World Health Organization (WHO), Urban health (2008). Pregledano 20. 09.2011. (http://www.euro.who.int/en/what-we-do/health-topics/environmental-health/urban-health). 
Lana Slavuj

Faculty of Science, Department of Geography, University of Zagreb, Croatia

e-mail: Islavuj@geog.pmf.hr

\title{
Life Quality in Urban Neighbourhood - Advantages and Drawbacks of Immediate Living Environment
}

\begin{abstract}
In the last few decades a number of projects and programs directed at improving urban quality of life have been initiated. Their main aim is to systematically measure and evaluate trends in the urban environment with a set of specific indicators relevant for the everyday quality of people's life. This paper deals with the quality of life in the selected neighbourhoods of the city of Rijeka. The selected neighbourhoods are: Belveder/Brajda-Dolac, Pećine, Pehlin, Orehovica and Pašac. The main research method was a questionnaire survey conducted in August, 2010 on a systematic random sample of inhabitants older than 18. Three hundred and sixty-five respondents participated in the questionnaire survey. In the first part of the paper, overall experience of urban life quality is examined using neighbourhood satisfaction as indicator. Neighbourhood is considered the most relevant scale on which to measure urban quality of life because it represents the immediate living environment where most daily activities take place. The second part of the paper analyses the respondents' answers about the major advantages and disadvantages of their neighbourhood, their suggestions how to improve the neighbourhood life quality and their opinion about the direction their neighbourhood life quality will take in the next five years. The comparison of city neighbourhoods and the identification of problems and advantages of the examined city areas can provide a solid information base for the citizens and local decisions makers about some trends in the life quality of the selected neighbourhoods, as well as help develop new projects and actions for their improvement.
\end{abstract}

Key words: urban quality of life, projects for monitoring urban quality of life, neighbourhood satisfaction, neighbourhood advantages and disadvantages, city of Rijeka. 